\title{
HUKUM SEBAGAI INTERPRETASI
}

\author{
Petrus CKL Bello*
}

\begin{abstract}
The issue of interpretation is one of the major themes in the study of law and legal practices. N onethel ess, whilelegal interpretation plays a crucial role in the study of law, scholars have yet to reach an agreement about its natureand status in the discipline. One of themost prolific legal philosophers who is deeply engaged in the discourse of this issueis Ronald Dworkin. This articlewill examine his views on law as an interpretation. The constructive interpretation model that Dworkin devel ops has posed a serious challenge for analytical jurisprudence in general, and especially, for legal positivism. The challengeis substantive and methodological; substantive, in the sense that it seeks to radically criticize a sharp separation between law and morality as prevalent in legal positivism, and methodological in the sense that it seeks to put together theanalysis of legal concepts with theinterpretation of law as it is regarded from the perspective of particular legal cases. Through the concept of law as interpretation, Dworkin wishes to formulate his own understanding of law as a coherent system of legal principles.
\end{abstract}

Keywords: Ronald Dworkin, constructiveinterpretation model, external and internal skepticism, theory of law, rights thesis, difficult cases.

Abstrak: Persoalan interpretasi merupakan salah satu tema besar dalam studi hukum dan praktik hukum. Kendati demikian, sementara interpretasi hukummemainkan peran krusial dalam studi hukum, para pakar masih belum sepakat mengenai hakikat dan kedudukannya dalam disiplin ilmu tersebut. Salah seorang ahli filsafat hukum yang sangat produktif dan sangat serius menggeluti persoalan ini adalah Ronald Dworkin. Artikel ini akan mengkaji pandangan Dworkin tentang hukum sabagai sebuah interpretasi. Model interpretasi konstruktif yang dikembangkan oleh Dworkin merupakan tantangan yang sangat serius bagi yurisprudensi analitis pada umumnya, dan khususnya bagi

* Petrus CKL Bello, Bello and Partners, Gedung A rthaloka Lt. 7, Suite707, JI.Jend. Sudirman Kav. 2, Jakarta Pusat 10220. Telepon: (021)2512475-76.E-mail: bellopartner@cbn.net.id. 
positivismehukum. Tantangan ini bersifat substantif dan metodologis. Bersifat substantif dalam arti bahwa Dworkin mengkritik secara radikal pemisahan yang begitu tajam antara hukum dan moral itas seperti lazim terjadi dalam positivismehukum. Tantangan ini juga bersifat metodologis dalam arti bahwa tantangan tersebut berkehendak menyatukan analisis atas konsep hukum dengan interpretasi terhadapnya, dipandang dari perspektif kasus-kasus hukum partikular. M elalui konsep hukum sebagai interpretasi, Dworkin ingin memformulasikan pemahamannya tentang hukum sebagai sebuah sistem prinsip-prinsip hukum yang koheren.

Katakata kunci: Ronald Dworkin, model interpretasi konstruktif, skeptisismeeksternal dan internal, teori hukum, tesis hak, kasus-kasus sulit.

\section{PENDAHULUAN}

Interpretasi merupakan ciri pokok dari hukum dan praktik hukum. Bahkan, bagi sebagian teoritikus hukum, interpretasi adalah fondasi bagi hukum. Kendati demikian dari sekian banyak diskusi perihal interpretasi di kalangan para teoritikus hukum masih terdapat ketidaksepakatan yang luas perihal hakikat interpretasi dalam hukum. Arti penting interpretasi dalam hukum tercermin dari pernyataan yang sering mengemuka di kalangan para pemikir hukum bahwa pemahaman kita tentang apa itu hukum akan bergantung pada pemahaman yang tepat tentang kedudukan interpretasi dalam hukum.

Persoalan interpretasi juga memainkan peran sangat penting dalam teori hukum Ronald Dworkin. Pandangan Dworkin yang menyatakan hukum sebagai interpretasi merupakan tantangan terhadap jurisprudensi analitis umumnya dan positivisme hukum khususnya. Tantangan tersebut sekaligus bersifat substantif dan metodologis. Substantif dalam artian Dworkin berkehendak membatalkan klaim para positivis (hukum) yang secara ketat membedakan antara hukum di satu pihak dan moralitas di lain pihak. Sedangkan secara metodologis, argumentasiargumentasi Dworkin seputar hukum sebagai interpretasi bermaksud menggusur distingsi tradisional antara analisis terhadap konsep hukum 
dan interpretasi atas pertanyaan apa itu hukum dengan berpijak pada kasus-kasus partikular. ${ }^{1}$

Teori hukum Ronald Dworkin dimaksudkan untuk menyediakan jalan keluar atas kebuntuan yang dihadapi oleh liberalisme yang menekankan pentingnya hak dan kebebasan individual dan positivisme hukum yang memberi penekanan pada kategorisasi yang ketat. Untuk proyeknya tersebut Dworkin bertolak dari pertanyaan pokok bagaimana meng-integrasikan teori dan praktik dalam hukum serta bagaimana memahami pengoperasian nilai-nilai dalam teori hukum dan ajudikasi? Dengan mengajukan konsep hukum sebagai interpretasi itu Dworkin bermaksud menggeser persoalan-persoalan utama yang berlaku dalam yurisprudensi dari level aturan-aturan dan tata bahasa (grammar) sistem hukum yang abstrak kelevel penerapan dan tindakan interpretasi hukum. Dworkin memahami konstruksi hukum sebagai keseluruhan yang memiliki tujuan (purposeful) dan mempunyai makna (meaningful). Praktik hukum, khususnya ajudikasi, dengan demikian, dirumuskan sebagai ikhtiar pencarian makna dan mendesakkan interpretasi yang bertujuan. ${ }^{2}$

Kendati demikian, pemikiran Dworkin perihal hukum sebagai interpretasi tidak datang begitu saja. Pemikiran tersebut lahir sebagai suatu tanggapan kritis atas pemikiran pendahulunya yaitu H.L.A. Hart, salah seorang filosof hukum paling berbobot dari abad ke-20. Hart, dalam maha karyanya The Concept of Law, ${ }^{3}$ berpandangan bahwa tugas utama

1 Bdk Andrei Marmor, Interpretation and Legal Theory (Oxford: Hart Publishing, 2005), p. 27.

2 Lihat Costas Douzinas, et.al., "Is Hermes Hercules' Twin? Hermeneutics and Legal Theory," in Reading D workin Critically edited by Alan Hunt (Oxford: Berg Publisher, Inc., 1992), pp. 123- 125. Dal am buku ini juga disebutkan bahwa hermeneutika berasal dari bahasa Yunani Hermenuein yang berarti menafsirkan, memahami makna-makna teks. Istilah tersebut berasal dari Hermes, pembawa pesan dari dewa-dewa, mediator antara yang ilahi dan yang sekular; tugas Hermes ialah menafsirkan kebijaksanaankebijaksanaan dari yang satu keyang lain. Dalam tulisan tersebut Douzinas menunjukkan keterkaitan antara konsep Dworkin tentang interpretasi dengan tradisi pemikiran hermenutika sebagaimana dikembangkan Gadamer, Habermas, dan Ricoeur. Dworkin sendiri mengulas tema hermeneutika (Gadamer, Dilthey, Habermas, dll.) dalam bukunya Law's Empire (Massachusetts: The Belknap Press of Harvard University Press, 1986), pp. 420-423.

3 H.L.A. Hart, The Concept of Law (Oxford University Press, Oxford, 1994), p. 132. 
filsafat hukum ialah menyediakan analisis atas konsep hukum dan atas konsep-konsep yang secara esensial berkaitan erat dengan pemahaman kita tentang hukum dan sistem-sistem hukum. Hart percaya bahwa suatu analisis konseptual yang seksama atas model-model analisis yang menekankan konsep-konsep dan makna-makna akan dapat menempatkan dasar-dasar intelektual bagi suatu pemeriksaan kritis dan rasional atas hukum yang bebas dari mitos-mitos moralitas.

Dworkin mengklasifikasikan pendekatan analitis atas hukum seperti dikemukakan Hart di atas dengan sebutan the semantic sting (sengatan semantik). Istilah ini merujuk pada model teori hukum yang mendasarkan penjelasan-penjelasannya pada teori semantik atau arti kata. Teori hukum jenis ini bertolak dari keyakinan bahwa penjelasan memadai tentang apa itu hukum pada akhirnya adalah sebuah penjelasan terperinci mengenai apa makna dari hukum; serta adanya aturan-aturan bersama dalam hal penggunaan sebuah kata. Maksudnya, aturan-aturan yang disepakati bersama baik oleh para ahli maupun oleh pelaku praktik hukum menjadi kriteria bagi suatu arti kata tertentu. ${ }^{4}$

Dworkin mengidentifikasi adanya dilema dalam "sengatan semantik." Pertama, jika semua ahli hukum menggunakan kriteria yang sama, maka ketika mereka terlibat sebuah perselishan misalnya dalam kasus-kasus sulit perselisihan tersebut akan dianggap sebagai sebuah perselisihan semu. Kedua, jika para pelaku praktik hukum tidak menggunakan kriteria yang sama, maka mereka menggunakan kata-kata sama tetapi dengan arti yang berbeda-beda. Dengan kata lain, sesungguhnya tidak ada kesepakatan yang benar-benar mencerminkan ketidaksepakatan. $^{5}$

Menanggapi kesulitan-kesulitan yang dihadapi teori hukum berbasis semantik Dworkin kemudian mengembangkan kosepsinya tentang hukum sebagai interpretasi. Meskipun demikian, hukum sebagai interpretasi yang diketengahkan oleh Dworkin tidak dimaksudkan untuk

4 Lih. Ronald Dworkin, Law's Empire, pp. 32; 45.

5 Ronald Dworkin, Law's Empire, pp. 45-46. 
menggantikan teori hukum berbasis teori semantik tetapi lebih sebagai kompetitor bagi teori hukum berbasisteori semantik baik dari segi metode maupun dari segi substansi. ${ }^{6}$

Tulisan ini akan memaparkan konsep hukum sebagai interpretasi dengan menjadikan pemikiran Ronald Dworkin sebagai pijakan konseptual nya. Untuk mempermudah, pembacaan tulisan akan mengikuti alur sebagai berikut. Pertama, pendahuluan yang berisi uraian singkat tentang apa yang akan dibahas dalam artikel ini. Kedua, kedudukan hukum sebagai interpretasi dalam menyikapi kasus-kasus sulit. Dalam bagian ketiga dijelaskan model interpretasi konstruktif yang dikembangkan Dworkin. Bagian keempat memaparkan pandangan Dworkin tentang skeptisisme eksternal dan internal atas interpretasi. Tulisan diakhiri dengan kesimpulan.

\section{INTERPRETASI DAN KASUS-KASUS SULIT}

Pandangan Dworkin tentang kasus-kasus sulit atau kasus-kasus kontroversial terdapat dalam tulisannya yang berjudul $\mathrm{H}$ ard $\mathrm{C}$ ases. ${ }^{7} \mathrm{H}$ ard Cases termasuk tulisan awal dari Dworkin di mana ia mulai memperkenalkan konsep tentang interpretasi. Mengenai status intepretasi dalam kasus-kasus sulit posisi teoritik Dworkin tercermin dari pernyataannya: “integritas adalah kunci bagi intepretasi konstruktif atas praktik-praktik hukum kita yang jelas dan khususnya berkaitan dengan cara para hakim kita memutuskan kasus-kasus sulit dalam hukum."8

Gagasan penting lain dari Dworkin yang mengemuka dalam $\mathrm{H}$ ard Cases ialah berkaitan dengan apa yang disebutnya sebagai "tesis hak" (rights thesis) yang berbunyi "putusan-putusan yudisial dalam kasus-kasus sipil, bahkan dalam kasus-kasus sulit ... secara khas harus dihasilkan lewat

6 Perihal metode dan susbtansi ini lihat catatan kaki no. 1 di atas.

7 Tulisan ini terdapat dalam Ronald Dworkin, Taking Right Seriously (Massachusetts: Harvard University Press, 1977), pp. 81-130.

8 Terjemahan dari teks asli: “Integrity is the key to the best constructive interpretation of our distinct legal practices and particularly of the way our judges decide hard cases at law." Ronald Dworkin, Law's Empire, p. 216. 
prinsip bukan (melalui) kebijakan." ${ }^{9}$ Tesis hak ini, dengan penekanan pada prinsip (tentang prinsip akan dijelaskan lebih jauh di bawah), merupakan tanggapan kritis Dworkin atas pemikiran Hart tentang diskresi yudisial tetapi pada saat bersamaan tesis hak juga adalah salah satu pijakan konseptual utama yang sangat menentukkan pemikiran Dworkin tentang hukum sebagai interpretasi.

Menurut Hart kasus-kasus sulit mencuat ke permukaan disebabkan karena adanya "tekstur terbuka" (open texture) dari sebuah aturan hukum. ${ }^{10}$ Untuk menyikapi kasus-kasus sulit yang bertumpu pada tekstur terbuka ini seorang hakim kemudian diharuskan melakukan diskresi. Dalam kata-kata Hart,

Dalam kasus-kasus ini hal itu menjadi jelas bahwa otoritas pembuat aturan harus menerapkan sebuah diskresi dan tidak ada kemungkinan bagi perhatian khusus pada persoalan yang dimunculkan oleh berbagai kasus seolah-olah terdapat satu jawaban yang tepat bersifat unik yang akan dapat ditemukan, yang terpisah dari suatu jawaban yang merupakan hasil kompromi masuk akal di antara begitu banyak kepentingan yang bertikai. ${ }^{11}$

Diskresi dilakukan hakim, dalam pandangan Hart, untuk menciptakan pilihan di antara alternatif-alternatif yang terbuka. Hakim, dengan demikian, terlibat dalam suatu laku kreatif. Dworkin tidak sependapat dengan Hart. Bagi Dworkin diskresi yang diajukan Hart termasuk ke dalam apa yang disebutnya "diskresi yang kuat" (strong discretion). Dalam

9 Ronald Dworkin, Taking Right Seriously, p. 84. Penekanan pada hak, termasuk prinsip di dalamnya, mengisyaratkan visi teori politik liberal yang diusung Dworkin sebagaimana dikatakannya ketika menjelaskan beda antara prinsip dan kebijakan: “argumen-argumen prinsip adalah argumen-argumen yang dimaksudkan untuk menetapkan sebuah hak individual. Argumen-argumen kebijakan adalah argumenargumen yang dimaksudkan untuk menetapkan sebuah tujuan kolektif. Prinsip-prinsip adalah proposisi-proposisi yang menjelaskan hak-hak; kebijakan-kebijakan adalah proposisi-proposisi yang menjelaskan tujuan-tujuan." Ronald Dworkin, Taking Right Seriously, p. 90.

10 H.L.A. Hart, The Concept of Law (Oxford: Oxford University Press, 1994), p. 123.

11 H.L.A. Hart, The Concept of Law, p. 132. 
diskresi ini hakim tidak lagi terikat oleh standar- standar apapun yang merefleksikan suatu otoritas hukum. ${ }^{12}$

Dworkin tidak setuju dengan pendirian $\mathrm{H}$ art tentang diskresi yudisial seperti disebutkan di atas. Menurut Dworkin para hakim tidak pernah bebas melakukan suatu diskresi yang kuat dalam memutuskan isu-isu tentang hukum, bahkan manakala pada kasus-kasus tersebut tidak ada aturan hukum yang tegas. Ketika seorang hakim menetapkan putusan-putusan berdasarkan sesuatu di luar aturan-aturan yang ada, hakim menurut Dworkin, harus mendasarkan putusan yang dibuatnya bukan pada standar-standar non-legal tetapi pada apa yang disebut Dworkin sebagai prinsip-prinsip (yang merupakan bagian dari hukum itu sendiri). ${ }^{13}$

Dworkin menyebutkan prinsip-prinsip untuk menerangkan berbagai macam norma-norma atau standar-standar yang berbeda dari kebijakan (policy) dan prinsip-prinsip moral dalam artiannya yang sempit. Tetapi terkadang, misalnya dalam kritiknya terhadap Hart, Dworkin membedakan antara prinsip-prinsip (principles) dari aturanaturan (rules). Perbedaan antara prinsip-prinsip dan aturan-aturan ialah sebagai berikut.

Dilihat dari standar penerapannya aturan bersifat "semua atau tidak sama sekali," atau menentukan hasilnya (conclusive). Contoh, jika sebuah aturan valid menyatakan bahwa wasiat harus disaksikan oleh tiga orang, maka wasiat yang disaksikan oleh dua orang secara otomatis tidak dapat disebut wasiat yang sah. Karena itu, aturan juga biasa disebut bersifat konklusif sebab menentukan kasus yang diatur oleh aturan tersebut. Karena sifatnya yang konklusif maka aturan yang valid tidak bisa bertentangan dengan aturan lain. Jika terjadi pertentangan, seperti banyak terjadi dalam peraturan yang dikeluarkan Pemerintah Daerah akhir-akhir ini, maka dapat dipastikan salah satu aturan tersebut tidak valid.

12 Ronald Dworkin, Taking Right Seriously, p. 33.

13 Ronald Dworkin, Taking Right Seriously, pp. 22-23. 
Sebaliknya, prinsip-prinsip hukum tidak konklusif dan dapat berlawanan satu sama lain. Prinsip-prinsip, menurut Dworkin, memiliki "dimensi kadar." ${ }^{14}$ Karena itu, jika prinsip-prinsip bertentangan maka metode yang tepat untuk memecahkan konflik tersebut adalah memilih prinsip yang memiliki kadar yang lebih kuat dan mengabaikan prinsip yang kadarnya lebih lemah. Prinsip bahwa seseorang tidak boleh mengambil manfaat dari tindakan kriminalnya, misalnya, menurut Dworkin tidak bisa diterapkan secara konsisten dalam arti semua kasus harus tunduk pada prinsip tersebut. Dalam banyak kasus prinsip tersebut tidak dipakai dan banyak orang yang secara sah mendapatkan keuntungan dari perbuatan melawan hukum yang mereka lakukan. ${ }^{15}$

Seseorang mungkin telah melakukan pelanggaran hukum seperti melanggar kontrak atau perjanjian masa kerja untuk mendapatkan bayaran yang lebih tinggi di tempat lain. Karena telah melanggar kontrak orang tersebut akan membayar ganti rugi sebagaimana ditetapkan dalam kontrak; namun ketika ia pindah tempat kerja ia tetap mendapatkan manfaat, bayaran yang lebih tinggi dari perusahaan barunya.

Menurut Dworkin analisis hukum Hart yang hanya mengakomodasi aturan-aturan dan tidak memasukkan prinsip-prinsip membuatnya menjadi lemah. Dworkin, dengan begitu, beranggapan bahwa prinsip merupakan bagian tak terpisahkan dari hukum dan bahkan prinsipprinsip dapat membatalkan peraturan. Selain itu, Dworkin juga menekankan bahwa hakim tidak hanya terikat oleh aturan-aturan melainkan juga oleh prinsip-prinsip.

Menurut Dworkin kasus-kasus sulit akan memaksa para ahli hukum untuk secara kritis dan reflektif mengembangkan suatu teori tentang institusi-institusi politik ${ }^{16}$ dan secara bersamaan mengoperasikan teori

14 Roland Dworkin, Taking Rights Seriously, p. 26.

15 Roland Dworkin, Taking Rights Seriously, p. 25.

16 Institusi-institusi politik dalam pemikiran Dworkin mengacu pada lembaga-lembaga atau badan-badan dalam suatu negara demokratis tertentu (misal nya lembaga pengadilan, lembaga perwakilan rakyat) yang keberadaannya tidak bisa dipisahkan dari nilai-nilai, sejarah dan konvensi-konvensi dari negara tersebut. Dengan kata 
tersebut untuk menentukan prinsip-prinsip moral yang "dapat menyediakan justifikasi bagi putusan-putusan tertentu." 17 Justifikasi tersebut akan tercapai jika prinsip yang dikutip konsisten dengan putusan-putusan yang terdapat dalam kasus-kasus sulit sebelumnya. ${ }^{18}$ Konsistensi dimaksudkan Dworkin sebagai konsistensi dalam penerapan prinsip yang dijadikan sandaran oleh suatu putusan tertentu. Dalam kata-kata Dworkin: Consistency here, of course, means consistency in the application of the principle relied on. ${ }^{19}$

Dari keterangan di atas terlihat bahwa kasus-kasus sulit muncul dari karakter bahasa atau aturan-aturan yang mengisyaratkan tekstur terbuka atau ketidakjelasan (vagueness) di mana ketidakjelasan tersebut menurut Dworkin harus diinterpretasikan oleh hakim. Pandangan Dworkin tentang interpretasi serta bagaimana hubungannya dengan prinsip akan dijelaskan pada uraian berikut ini.

\section{DWORKIN DAN INTERPRETASI KONSTRUKTIF}

Dalam diskursus ilmu-ilmu sosial dikenal adanya distingsi konseptual antara fakta dan nilai, kebenaran dan cita rasa, individu dan masyarakat, kebebasan dan paksaan, rasio dan prasangka. Hal tersebut berlaku juga dalam kajian hukum misalnya distingsi konseptual antara fakta dan nilai. Dalam wacana seputar teori hukum distingsi fakta dan nilai termanifestasikan dalam distingsi antara apakah hukum berkutat dengan tema 'yang seharusnya' (law is ought to be) atau bergulat dengan 'apa yang senyatanya ada' (law as it is) atau sebagaimana dikemukakan Dworkin sendiri ketika ia membedakan antara prinsip (principle) dengan kebijakan (policy). ${ }^{20}$ Interpretasi yang dikembangkan Dworkin dimaksud-

lain, bagi Dworkin teori hukum adalah sebuah teori yang pada keseluruhannya mencakup juga persoalan-persoalan moralitas dan filsafat politik. Lih. Ronald Dworkin, Taking Rights Seriously, pp. 101-102.

17 Ronald Dworkin, Taking Right Seriously, pp. 22; 88.

18 Ronald Dworkin, Taking Right Seriously, p. 88.

19 "Konsistensi di sini, tentu saja, berarti konsistensi dalam hal penerapannya pada prinsip yang dijadikan sandaran." Ronald Dworkin, Taking Right Seriously, p. 88.

20 Lihat Ronald Dworkin, Taking Right Seriously, pp. 22; 82. 
kan untuk memediasi ketegangan-ketegangan oposisional yang berlaku dalam teori hukum tersebut.

Konsep hukum sebagai interpretasi dari Dworkin berkaitan erat dengan pandangannya tentang apa yang disebut tesis hak (rights thesis) sebagaimana telah diterangkan dalam sub-bahasan interpretasi dan kasus-kasus sulit. Tesis hak ini berhubungan dengan pandangan Dworkin tentang "jawaban yang tepat;" dalam konteks kasus-kasus sulit Dworkin berkeyakinan bahwa, "terdapat jawaban tepat tunggal disetiap perselisihan yang terjadi dalam masalah hukum"21 dan bagi Dworkin hukum adalah "sebuah konsep interpretatif"(law is an interpretive concept). ${ }^{22}$

Untuk dapat memahami posisi teoritis Dworkin di atas baik jika terlebih dahulu kita ikuti kisah imajiner yang diajukan Dworkin dalam Law's Empire. ${ }^{23}$ Dworkin mengajak kita untuk membayangkan adanya sebuah komunitas. Para anggota komunitas memiliki seperangkat aturan-aturan yang dibutuhkan bagi bentuk-bentuk perilaku tertentu dalam situasi-situasi tertentu. Para anggota komunitas menyebut aturanaturan tersebut sebagai "aturan-aturan kesopanan" (rules of courtesy). Salah satu aturan kesopanan yang berlaku ialah "para petani harus menanggalkan topi yang dikenakan untuk menghormati kaum bangsawan."24

Pada awal nya anggota-anggota komunitas sekedar mengikuti begitu saja aturan kesopanan menanggalkan topi bagi para petani tersebut. Pada tahap ini sikap yang ditunjukkan anggota komunitas berada dalam suatu sikap yang tidak reflektif. Pada perkembangan berikutnya mereka secara perlahan mengembangkan suatu sikap yang reflektif atau dalam

21 Lih., “Can Rights be Controversial?," dalam Ronald Dworkin, Taking Rights Seriously, p. 279.

22 Ronald Dworkin, Law's Empire, p. 87. Bandingkan juga dengan pernyataannya tentang interpretasi konstruktif dalam catatan kaki nomor 19.

23 Ronald Dworkin, Law's Empire, pp. 46, 48.

24 "Courtesy requires that peasants take off their hats to nobility." Ronald Dworkin, Law's Empire, pp. 47, 48. 
istilah Dworkin "sikap interpretatif yang kompleks terhadap aturanaturan kesopanan."

Menurut Dworkin sikap interpretatif yang kompleks ini memuat dua komponen. Pertama, asumsi yang menyatakan bahwa praktik kesopanan tidak semata-mata ada tetapi praktik tersebut mengisyaratkan adanya nilai tertentu; sebuah nilai yang disajikan bagi minat, tujuan, atau penerapan prinsip. Kedua, asumsi yang menyatakan bahwa kebutuhan akan kesopanan tidak bersifat niscaya atau bersifat eksklusif dalam artian para anggota komunitas harus selalu melakukan aturan kesopanan tersebut tetapi sebaliknya aturan-aturan yang ketat harus selalu dapat dipahami, dimodifikasi, diperluas, dan dibatasi sesuai dengan nilai yang terkandung dalam aturan kesopanan. Pada komponen kedua ini, menurut Dworkin, terlihat bahwa seseorang yang menjadi anggota komunitas sedang mencoba untuk mendesakkan pemaknaan (baca: melakukan interpretasi) pada aturan-aturan kesopanan; mencoba memahaminya dengan sebuah pemaknaan terbaik dan berusaha untuk terus menata ulang aturan-aturan kesopanan tersebut dengan cara menyesuaikannya dengan hasil-hasil pemaknaan yang dilakukan.

Meskipun demikian, interpretasi yang ditekankan Dworkin bukanlah sebuah interpretasi yang bertumpu pada percakapan (conversational) sebagaimana terjadi pada praktik-praktik sosial pada umumnya, tetapi sebaliknya interpretasi Dwokin bersifat konstruktif: "creativeinterpretation is not conversational but constructive." 25 Perbedaan antara interpretasi yang berbasis pada percakapan dengan interpretasi konstruktif ialah sementara percakapan berupaya menafsirkan maksud atau tujuan pengarang atau pembicara, interpretasi konstruktif mengandaikan adanya hubungan timbal balik antara objek dengan tujuan yang disandarkan pada apa yang disebut sebagai prinsip atau nilai-nilai yang terbaik. ${ }^{26}$

25 Ronald Dworkin, Law's Empire, p. 52.

26 Bdk. Ronald Dworkin, Law's Empire, p. 413. 
Pendapat Dworkin berikut ini memperlihatkan bagaimana proses penyematan prinsip atau nilai dalam laku interpretasi:

Kami selanjutnya akan mengatakan bahwa semua interpretasi mengupayakan penciptaan suatu objek sebaik mungkin, sebagaimana pada kegiatan lain yang serupa, dan bahwa interpretasi mengambil bentukbentuk yang berdeda dalam konteks-konteks yang berbeda hanya dikarenakan kegiatan yang berbeda-beda melibatkan standar-standar nilai atau keberhasilan yang berbeda-beda pula. Interpretasi artistik berbeda dari interpretasi saintifik, akan kami nyatakan, hanya karena kami memutuskan keberhasilan dalam karya-karya seni dengan menggunakan standar-standar yang berbeda dari standar-standar yang digunakan untuk menilai penjelasan-penjel asan tentang gejal a fisik. ${ }^{27}$

Argumentasi utama Dworkin perihal hukum sebagai interpretasi ialah sebagai berikut: hukum adalah sebuah laku interpretatif. Interpretasi hukum mirip dengan interpretasi terhadap teks-teks sastra. Bagi Dworkin keseluruhan interpretasi bersifat konstruktif dalam artian laku interpretasi tersebut memaksakan sebuah keterarahan pada sebuah objek, mendudukkan atau menjadikannya sebagai sebuah contoh terbaik yang mungkin diraih dari bentuk atau genre. Secara lebih lengkap pendapat Dworkin tersebut ialah sebagai berikut:

Interpretasi karya-karya seni dan praktik-praktik sosial, akan saya nyatakan, memang pada dasarnya berhubungan dengan tujuan tidak dengan sebab-musabab. Tetapi, tujuan-tujuan dalam drama (secara fundamental) tidak berkaitan dengan beberapa pengarang melainkan dengan penafsir. Secara umum, interpetasi konstruktif adalah suatu persoalan melekatkan tujuan pada suatu objek atau praktik dalam rangka menjadikannya sebagai contoh terbaik yang mungkin dirai $h .{ }^{28}$

27 "We would then say that all interpretation strives to make an object the best it can be, as an instance of some assumed enterprise, and that interpretation takes different forms in different contexts only because different enterprise engage different standards of value or succes. A rtistic interpretation differs from scientific interpretation, we would say, only because we judge success in works of art by standards different from those we usetojudgeexplanations of physical phenomena." Ronald Dworkin, Law's Empire, p. 53.

28 "Interpretation of works of art and social practices, I shall argue, is indeed essentially concerned 
Interpretasi secara esensial selalu berkaitan dengan pemaknaan. Interpretasi dengan begitu berkutat dengan suatu laku pemaknaan atas sesuatu yang terekspresikan di hadapan kita, teks hukum atau lainnya. Dalam hal pemaknaan, seorang penafsir atau interpreter selalu berupaya untuk mengetahui maksud atau intensi penulis yang ada di balik gugusan teks yang diinterpretasi. Konsepsi Dwokin tentang hukum sebagai interpretasi juga berkutat pada persoalan maksud-maksud di balik teksteks tertentu. Maksud-maksud atau intensi-intensi tersebut lalu dikonstruksikan sedemikian rupa secara hipotetis. ${ }^{29}$

Pendapat Dworkin yang dikutip di atas sekurang-kurangnya bekaitan dengan tiga hal utama dalam model interpretasi konstruktif. Pertama, interpretasi berupaya untuk menghadirkan objek-objek yang ditafsir dalam terang kemungkinan tafsir terbaik. Ketiga, interpretasi secara esensial bergantung pada genre (genre-dependent), maksudnya, proses interpretasi tidak berdiri sendiri, interpretasi tidak terasing dari dari objek-objek atau praktik sosial tertentu. Ketiga, terdapat batasanbatasan yang menentukan batas-batas bagi interpretasi-interpretasi yang mungkin atas suatu objek tertentu. ${ }^{30}$

\section{SKEPTISISME EKSTERNAL DAN INTERNAL ATAS INTERPRETASI}

Sebelum menjelaskan masalah skeptisisme eksternal dan internal atas interpretasi terlebih dahulu akan dijelaskan tentang tahapan-tahapan dalam proses interpretasi. Menurut Dworkin, sekurangnya ada tiga tahapan dalam melakukan interpretasi, yakni tahap pra-interpretatif, tahap interpretatif, dan tahap pasca-interpretasi. ${ }^{31}$

with purpose not cause. But the purposes in play are not (fundamentally) those of some author but of the interpreter. Roughly, constructive interpretation is a matter of imposing purpose on an object or practice in order to make of it the best possible example of the form or genreto which it is taken to belong." Ronald Dworkin, Law's Empire, p. 52.

29 Bdk. Andrei Marmor, Interpretation and Legal Theory, p. 28.

30 Bdk. Andrei Marmor, Interpretation and Legal Theory, p. 28.

31 Ronald Dworkin, Law's Empire, pp. 65-66. 
Dalam tahap pra-interpretatif seorang penafsir (interpreter) harus mengenali data-data yang belum ditafsirkan. Dalam praktik hukum datadata ini misalnya adalah aturan-aturan, standar dan perilaku yang berkaitan dengannya. Pada tahap interpretatif penafsir harus menetapkan elemen pokok dari praktik hukum dan memberikan alasan atau justifikasi bagi penetapannya akan elemen pokok tersebut. Dan pada tahap pascainterpretatif atau tahap pembentukan ulang (reforming), penafsir menyesuaikan pemahamannya dengan praktik yang sungguh-sungguh diperlukan, demi menjadikan praktik tersebut lebih baik untuk dijadikan sebagai basis untuk justifikasi bagi praktik-praktik yang diterima pada tahap interpretatif.

Menurut Dworkin dengan melibatkan diri dengan proses interpretasi seorang interpreter harus selalu mempunyai beberapa asumsi dan keyakinan. Beberapa asumsi dan keyakinan tersebut meliputi pada tahap pertama (pra-interpretatif) seorang penafsir membutuhkan asumsi atau keyakinan perihal pemilihan mana yang ditetapkan sebagai bagian dari praktik-praktik dan mana yang bukan merupakan bagian dari praktikpraktik. Proses identifikasi dan klasifikasi ini diperlukan terutama untuk menentukan data-data mentah yang hendak diinterpretasi pada tahap pra-interpretasi ini. ${ }^{32}$

Pada tahap kedua (interpretasi) keyakinan-keyakinan yang diperlukan seorang penafsir berpusat pada persoalan sejauh mana justifikasi yang diajukannya dalam tahap interpretasi ini cocok atau sesuai dengan aspek-aspek dari praktik interpretatif yang telah ada, yang juga dipertimbangkan sebagai porses interpretasi. Dengan kata lain, ia tidak menemukan sesuatu yang baru. ${ }^{33}$

32 Ronald Dworkin, Law's Empire, p. 67.

33 Ronald Dworkin, Law's Empire, p. 67. Hal ini memperlihatkan perbedaan antara pemikiran Hart, khususnya tentang diskresi yudisial, dengan pemikiran Dworkin. Diskresi yudisial Hart, yang oleh Dworkin digolongkan sebagai diskresi yudisial kuat, bertujuan menciptakan sebuah putusan yudisial yang baru sebagai respons atas kasus-kasus sulit. Dworkin, sebaliknya, berpendapat bahwa putusan tersebut tidak benar-benar baru karena dalam memutuskan kasus-kasus sulit seorang hakim selalu diikat oleh 'aturan main' yang telah disepakati dan diyakini oleh para hakim yang mana aturan main tersebut mendasarkan dirinya pada prinsip-prinsip yang ada. 
Pada tahap ketiga (pasca-interpretatif) seorang penafsir membutuhkan keyakinan-keyakinan yang, menurut Dworkin, lebih substansial yakni berkaitan dengan jenis justifikasi yang akan memperlihatkan atau memposisikan suatu praktik dalam statusnya yang paling baik (best light). ${ }^{34}$ Melalui keyakinan atau asumsi yang disebutkan terakhir ini akan dimungkinkan munculnya nilai-nilai paling utama dari seorang penafsir. Melalui konsep interpretasi ini Dworkin mau menentang pandangan positivisme hukum yang mengatakan bahwa penelitian hukum hanya mendeskripsikan bukan mengkritik atau mencita-citakan sebuah praktik hukum yang lebih baik.

Menurut Dworkin terdapat pandangan-pandangan yang meragukan proyek interpretasinya. Dworkin mengistilahkan pandangan-pandangan tersebut sebagai skeptisisme eksternal dan skeptisisme internal dan menurut Dworkin hanya skeptisisme internal yang dianggapnya berbobot. ${ }^{35}$ Seorang skeptikus eksternal, demikian menurut Dworkin, tidak mengatakan bahwa adalah sebuah kekeliruan memikirkan sebuah drama (dalam hal ini $\mathrm{H}$ amlet) sebagai memuat sebuah tujuan atau nilai moral

34 Ronald Dworkin, Law's Empire, hal. 67.

35 Ronald Dworkin, Law's Empire, pp. 78-86. Ilustrasi Dworkin untuk kedua istilah tersebut sebagai berikut: Seseorang berpendapat bahwa drama Hamlet (salah satu karya sastrawan besar William Shakespeare) sangat tepat dipahami sebagai sebuah drama yang mengeksplorasi kegilaan, penggandaan, dan ketertundaan. Menurut orang tersebut, Hamlet menampilkan suatu integritas artistik dalam tema-tema narasinya, kesatuan leksikal dan retorikanya tertata sangat baik. Kepada orang tersebut seorang skeptikus internal akan berkata: "Anda salah. Hamlet sangat membingungkan, mencampuradukkan segala hal, gado-gado dalam sebuah drama." Sementara itu, seorang skeptikus eksternal akan berkata: "Saya sependapat dengan Anda. Sayajuga berpikiran bahwa pentas Hamlet adal ah pembacaan yang sangat mengesankan atas sebuah naskah drama. Meski demikian, masih menurut skeptikus eksternal, ini sekadar pendapat kami saja tetapi kami tetap tidak bisa menyadari anggapan bahwa keseluruhan aspek dalam Hamlet adalah fakta objektif sesungguhnya, yang terdapat dalam hakikat realitas, kenyataan yang berada di luar sana, pada dunia transendendal di mana maknamakna dalam drama tersebut berada." Jelaslah bahwa seorang skeptikus internal akan mengajukan keberatan-keberatannya dengan bertolak dari, katakan, logika internal yang terdapat dalam suatu praktik tertentu. Tetapi sebaliknya, seorang skeptikus eksternal tidak akan mengajukan keberatan-keberatan berarti atas suatu praktik tertentu tetapi ia meragukan secara radikal bahwa praktik-praktik tersebut memiliki kaitan langsung dengan fakta-fakta objektif dan empirik. Pendek kata, skeptikus eksternal menganggap praktik-praktik itu sebagai mitos. 
tertentu; atau dengan kata lain adalah keliru menganggap bahwa sebuah praktik sosial memiliki nilai moral. Sebaliknya yang dikatakan skeptikus eksternal ialah peryataan-pernyataan yang terlibat dalam keseluruhan tahap interpretasi bukan merupakan deskripsi-deskripsi yang dapat dibuktikan, diuji, atau dipertanggungjawabkan secara ilmiah seperti halnya fisika. ${ }^{36}$

Kritik internal mempunyai dan menyampaikan pendapat-pendapatnya sendiri berkaitan dengan interpretasinya atas suatu drama, tetapi sebaliknya skeptikus eksternal sekadar menyatakan bahwa semua pendapat-pendapat (baca interpretasi) tersebut adalah sesuatu yang diproyeksikan, tidak akan dapat ditemukan dalam realitas. ${ }^{37}$ Dengan kata lain, skeptikus eksternal sangat mendasarkan argumentasinya pada fakta bahwa pandangan-pandangan moral dari satuan-satuan kebudayaan berbeda satu sama lain. Mereka juga mendasarkan argumentasinya pada fakta bahwa bahkan dalam satu kebudayaan yang sama seringkali juga terdapat persel isi han-persel isi han. ${ }^{38}$ Tanggapan Dworkin atas argumentasi dari model skeptisismeeksternal ini ialah menurutnya penjelasan tersebut sama sekali tidak membuktikan bahwa tidak ada jawaban-jawaban yang tepat perihal persoalan-persoalan moralitas dan hukum.

Skeptikus internal, sebaliknya, meyakini bahwa tidak ada interpretasi atas praktik sosial atau apapun juga yang dapat menjadi benar atau salah; putusan-putusan tersebut berkenaan tentang isu-isu moral yang bersifat personal. Posisi semacam ini oleh Dworkin disebut sebagai “skeptisisme internal global"39 yang dipahami sebagai sebuah posisi intelektual yang rasional.

Kendati demikian Dworkin menyangsikan bahwa terdapat beberapa orang yang secara konsisten mengadopsi skeptisisme internal ini.

36 Ronald Dworkin, Law's Empire, pp. 79-80.

37 Ronald Dworkin, Law's Empire, p. 80.

38 Dalam bukunya yang terbaru Dworkin mengidentikkan skeptisisme jenis ini dengan posmodernisme. Lihat Ronald Dworkin, Justice for H edgehogs (Cambridge, MA: The Belknap Press of Harvard University Press, 2011), p. 30.

39 Ronald Dworkin, Law's Empire, pp. 79-84. 
Seseorang tidak dapat mengadopsi posisi skeptis internal dalam suatu perdebatan filosofis. Kemungkinan besar orang tersebut akan berbalik arah dan mengambil posisi, misalnya dalam konteks sikap moral atas praktik perbudakan yang dicontohkan Dworkin; bahwa praktik perbudakan adalah sesuatu yang tidak adil. Dengan kata lain, hal ini berseberangan dengan posisi konseptualnya yang menyatakan bahwa tidak ada interpretasi atas praktik sosial yang dapat menjadi benar atau salah. ${ }^{40}$ Setiap orang yang menyatakan bahwa perbudakan adalah salah, entah dia dalam posisi skeptikus eksternal atau internal, dengan sendirinya berkomitmen pada pemahaman bahwa memang terdapat sebuah jawaban yang tepat dalam persoalan tentang perbudakan.

\section{PENUTUP}

Merujuk pada pemaparan-pemaparan tentang konsepsi Dworkin mengenai hukum sebagai interpretasi pada umumnya dan tentang kedudukan interpretasi dalam kasus-kasus sulit, model interpretasi konstruktif, serta skeptisisme eksternal dan internal pada khususnya, kiranya dapat disimpulkan bahwa interpretasi adalah sesuatu yang sosial. Artinya, laku interpretasi berbasis pada gejala sosial dengan melibatkan nilai-nilai tertentu.

Dalam proses interpretasi, seorang penafsir akan mulai tindakannya dengan mengidentifikasi segala hal yang berkaitan dengan aneka praktik sosial —salah satunya hukum—seraya memahaminya sebagai mengandung suatu tujuan atau nilai. Praktik-praktik tersebut dielaborasi melalui suatu pemahaman yang berbasis pada keyakinan-keyakinan dan nilai-nilai personal. Di samping itu, bertolak dari pengandaian dasar bahwa terdapat satu jawaban yang tepat atas persoalan-persoalan yang menyangkut nilai dan kebenaran interpretatif (misalnya dalam kasuskasussulit), interpretasi adalah suatu laku yang anti terhadap sikap skeptis.

Dworkin berkeyakinan bahwa interpretasi memainkan peran sangat sentral dalam teori hukum. Segala permasalahan, baik dalam bidang 40 Ronald Dworkin, Law's Empire, p. 84. 
yurisprudensi yang bersifat konseptual maupun dalam ajudikasi yang bersifat praktik hukum, menurut Dworkin dapat dipahami dan dapat dijelaskan sebagai masalah dalam proses interpretasi. Permasalahan tersebut juga dapat dipecahkan melalui proses-proses interpretasi . Menurut hemat penulis, penekanan yang berlebihan tentang interpretasi ini berpotensi membawa teori hukum yang dikembangkan Dworkin pada kecenderungan reduksionistis, mereduksikan keseluruhan bentuk pemahaman sebagai bentuk-bentuk interpretasi.

\section{DAFTAR RUJUKAN}

Dworkin, Ronald. Justice for H edgehogs. Cambridge, MA: The Belknap Press of Harvard University Press, 2011. . Law's Empire. Cambridge, MA:TheBelknap Press of Harvard University Press, 1986. . Taking Right Seriously. Cambridge, MA: Harvard University Press, 1977.

Hart, H.L.A. The Concept of Law. Oxford: Oxford University Press, 1994. Hunt, Alan (Ed.). Reading Dworkin Critically. Oxford: Berg Publisher, Inc., 1992.

Marmor, A ndrei. Interpretation and Legal Theory. Oxford: H art Publishing, 2005. 